\title{
HIV-1 infection of microglial cells in a reconstituted humanized mouse model and identification of compounds that selectively reverse HIV latency
}

\author{
George N. Llewellyn ${ }^{1}$ • David Alvarez-Carbonell ${ }^{2} \cdot$ Morgan Chateau $^{1}$. \\ Jonathan Karn ${ }^{2}$ • Paula M. Cannon ${ }^{1}$
}

Received: 11 October 2017 /Revised: 3 November 2017 / Accepted: 9 November 2017 / Published online: 18 December 2017

(C) The Author(s) 2017. This article is an open access publication

\begin{abstract}
Most studies of HIV latency focus on the peripheral population of resting memory T cells, but the brain also contains a distinct reservoir of HIV-infected cells in microglia, perivascular macrophages, and astrocytes. Studying HIV in the brain has been challenging, since live cells are difficult to recover from autopsy samples and primate models of SIV infection utilize viruses that are more myeloid-tropic than HIV due to the expression of Vpx. Development of a realistic small animal model would greatly advance studies of this important reservoir and permit definitive studies of HIV latency. When radiation or busulfan-conditioned, immune-deficient NSG mice are transplanted with human hematopoietic stem cells, human cells from the bone marrow enter the brain and differentiate to express microglia-specific markers. After infection with replication competent HIV, virus was detected in these bone marrow-derived human microglia. Studies of HIV latency in this model would be greatly enhanced by the development of compounds that can selectively reverse HIV latency in microglial cells. Our studies have identified members of the CoREST repression complex as key regulators of HIV latency in microglia in both rat and human microglial cell lines. The monoamine oxidase (MAO) and potential CoREST inhibitor, phenelzine, which is brain penetrant, was able to stimulate HIV production in human microglial cell lines and human glial cells recovered from the brains of HIV-infected humanized mice.
\end{abstract}

Jonathan Karn

jxk153@ case.edu

Paula M. Cannon

pcannon@usc.edu

1 Department of Molecular Microbiology and Immunology, Keck School of Medicine, University of Southern California, Los Angeles, CA, USA

2 Department of Molecular Biology and Microbiology, School of Medicine, Case Western Reserve University, Cleveland, OH, USA
The humanized mice we have developed therefore show great promise as a model system for the development of strategies aimed at defining and reducing the CNS reservoir.

Keywords HIV latency · Epigenetic silencing · Humanized mice $\cdot$ Microglial cell

\section{Introduction}

Reservoirs of HIV persist in the body despite antiretroviral therapy (ART) (Barton et al. 2016; Boritz et al. 2016; Brew et al. 2015; Katlama et al. 2013). The reservoir includes populations of latently infected cells that can be reactivated and restart an infection when ART is interrupted. Most studies of HIV latency have focused on the central memory Tcells found in the peripheral circulation(Brew et al. 2015; Siliciano and Siliciano 2013; Spivak and Planelles 2016); however, the CNS contains a significant reservoir that is distinct from the T cell compartment that has often been neglected (reviewed in (Fois and Brew 2015; Hellmuth et al. 2015)).

Direct evidence for HIV infection of the brain has come from autopsy samples (Desplats et al. 2013; Thompson et al. 2011), with HIV DNA detected in astrocytes, perivascular macrophages, and microglia (Churchill et al. 2006; Thompson et al. 2011). Although astrocytes show infection rates up to $19 \%$ (Churchill et al. 2009), they produce little to no infectious virus (Gorry et al. 2003; Messam and Major 2000), suggesting that the source of persisting HIV in the CNS is instead the microglia or perivascular macrophages. Primary human microglia can be readily infected by HIV ex vivo (Garcia-Mesa et al. 2017; Jordan et al. 1991), and recent studies have shown that they are much more permissive to infection than macrophages from other tissues (Cenker et al. 2017).

Persistence of HIV in the CNS may be facilitated by suboptimal drug penetration across the blood-brain barrier, although 
there is little evidence for a high level of ongoing active replication in the CNS in well-suppressed patients or the emergence of drug-resistant strains (Bednar et al. 2015; Dahl et al. 2014; Gianella et al. 2016; Schnell et al. 2011). Virus also rebounds in the CNS after ART interruption, analogously to lymphoid tissues (Gianella et al. 2016). We therefore favor the hypothesis that HIV persists in the CNS due primarily to the establishment of latent HIV infections, especially in the microglial cell population, which is highly permissive for HIV infection (Cenker et al. 2017). Curing HIV will therefore require strategies that remove, disable, or suppress all latent HIV reservoirs, including those specific to the CNS (Brew et al. 2015; Fois and Brew 2015; Garrido and Margolis 2015).

Studies of HIV infection in the CNS are challenging, and have relied historically on post-mortem samples or on cell line models that may not fully recapitulate in vivo systems. Although primate SIV infection models have provided important insights about CNS infection, (Zink et al. 1999), the presence of Vpx in SIV, which counteracts the myeloid restriction factor SamHD1 and leads to enhanced infection of perivascular macrophages and microglial cells, means that some findings from the SIV models may not be translatable to HIV. There is therefore a pressing need to develop better animal models of HIV infection in the CNS that not only support infection of relevant human cell types, such as human perivascular macrophages and microglia, but also recapitulate features of the HIV life cycle, including the development of latency during ART.

Humanized mice are being explored as a readily accessible model for HIV CNS infection (Honeycutt et al. 2015). Early approaches included the direct injection of HIV-infected monocyte-derived macrophages into the brains of immunodeficient mice (Persidsky et al. 1996; Poluektova et al. 2002, 2004; Potula et al. 2005; Tyor et al. 1993). Although this can result in high levels of engraftment around the site of injection, the mice only survived up to 4 weeks post-injection, and the trauma caused by the injection itself induced potentially confounding levels of inflammation (Honeycutt et al. 2015). In contrast, systemic injection of human HSC into immune-deficient strains, such as NSG mice, creates humanized mice that support long-term engraftment of human cells in the blood and lymphoid tissues. Unfortunately, only low numbers of human cells have been observed in the brains of these mice by histology and qPCR (Honeycutt et al. 2016; Dash et al. 2011). When humanized mice are infected with HIV, p24+ cells can be detected in the brain (Gorantla et al. 2010; Honeycutt et al. 2016), and neuronal damage, inflammation, and increased mouse microglia proliferation have been reported (Dash et al. 2011; Boska et al. 2014; Gorantla et al. 2010), mimicking aspects of AIDSrelated dementia seen in untreated patients. Although some of the human cells in humanized mouse brains have been reported to express the microglia marker Ibal (Asheuer et al. 2004), none of the published studies have specifically demonstrated HIV-infected human microglia.
In the present study, we characterized the human cells present in the brains of NSG mice transplanted with human HSC and identified human cells expressing markers of microglia. Using specific conditioning regimens, up to $10 \%$ of the microglia in the brains of these animals were of human origin and could be readily infected by HIV in vivo. This is a critical first step to investigate whether latency can develop in the microglial cell population in vivo. Our previous studies of immortalized human microglial cells have shown that latency can readily develop in microglial cells due to the imposition of epigenetic restrictions (Alvarez-Carbonell et al. 2017; Garcia-Mesa et al. 2017). In order to develop tools to study latency in the humanized mouse model, we used these cell models to identify compounds that can potently and selectively reverse latency in microglial cells. Intriguingly, after isolation of the human microglial cells from the mice, viral reactivation was achieved using the monoamine oxidase (MAO) inhibitor phenelzine, suggesting that a subset of these cells may harbor latent proviruses.

\section{Results}

\section{Strategy for developing a humanized mouse model to study HIV latency}

Our strategy to repopulate the brains of immune-deficient NSG mice with human microglial cells was based on prior studies showing that depletion of CNS myeloid cells occurs following treatment with radiation (Eglitis and Mezey 1997), or by exposure of CD11b-HSVTK transgenic mice to intracerebroventricular ganciclovir (GCV) (Varvel et al. 2012), allows repopulation of such microglia-depleted brains by mouse peripheral monocytes. In the studies of Varvel et al. (2012), GCV depletion allowed the brains to become repopulated with bone marrow-derived monocytes that expressed high levels of CD45 and CCR2 and, upon entry into the brain, expressed the sentinel microglial marker Iba1. Although the infiltrating monocytes were two times more numerous and morphologically distinct from resident microglia, they became uniformly distributed throughout the brain, and had an overall distribution and behavior that was remarkably similar to that of microglia. In addition, work by Asheuer et al. (2004) demonstrated that the repopulating cells could also be derived from transplanted human bone marrow cells. Adapting and simplifying this method for use with HIV, we reasoned that NSG mice reconstituted with human hematopoietic stem cells would also contain cells that could differentiate into a microglial phenotype in the brain and subsequently support infection by HIV.

\section{Identification and quantification of human microglia in humanized NSG mice}

Humanized NSG mice were created by standard procedures using total body irradiation to condition adult mice, followed by transplantation with up to $10^{6}$ human CD34+ HSC (Holt 
et al. 2010; Wang et al. 2015) (Fig. 1 a). At the same time, we also evaluated an alternate conditioning regimen based on the chemotherapeutic agent, busulfan, since this has been reported to increase the frequency of donor HSC-derived microglia present in the brains of mice undergoing transplantation with mouse HSC (Wilkinson et al. 2013). The CD34+ cells used to generate these mice were isolated from a single source to eliminate human donor cell variation.

At 16-week post-transplantation, mice were euthanized, perfused with PBS to deplete contaminating blood cells from the brain, and the glial fraction was then isolated from brain tissue using a Percoll gradient. This fraction was immunostained for a human-specific marker (hCD45), as well as the microglial markers CD11b and P2RY12 (Fig. 1b-e) (Bennett et al. 2016; Butovsky et al. 2014). P2RY12 is a more specific marker for microglia than CD11b, which is also expressed on macrophages, but we observed that almost all the cells expressing either marker were both $\mathrm{P} 2 \mathrm{RY} 12^{+}$and $\mathrm{CD} 11 \mathrm{~b}^{+}$. We found both an increase in the overall frequency of human cells in the brains of busulfan-conditioned mice compared to the irradiated mice, and a corresponding increase in the frequency of human cells in the total $\mathrm{CD} 11 \mathrm{~b}^{+} \mathrm{P} 2 \mathrm{RY} 12^{+}$fraction, which includes both mouse and human microglia (Fig. 1e).

\section{HIV infection of microglia in the brain of humanized mice}

To determine whether the human microglia in the brains of humanized mice could be infected by HIV in vivo, we challenged five humanized mice with an R5-tropic strain of HIV, JRCSF-HA. This virus contains a surface expressed hemagglutinin (HA) epitope-tagged protein that can be used to identify productively infected cells by flow cytometry. Viremia was monitored in the blood of all animals over 12 weeks (Fig. 2a), at which point the mice were necropsied and the glial cells isolated and stained for hCD45, CD11b, and HA. We observed that $2-15 \%$ of the hCD $45+$ CD $11 b+$ cells were also positive for $\mathrm{HA}$, indicating the presence of productively HIV-infected microglia (Fig. 2b).

\section{a}

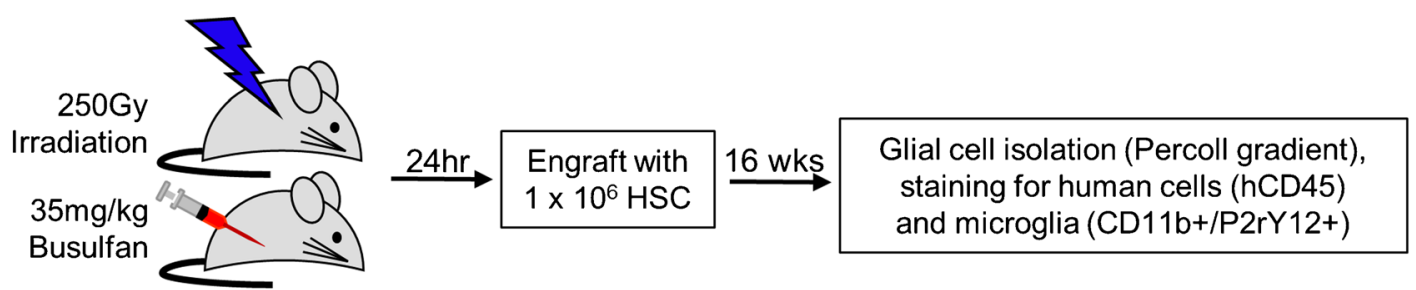

b

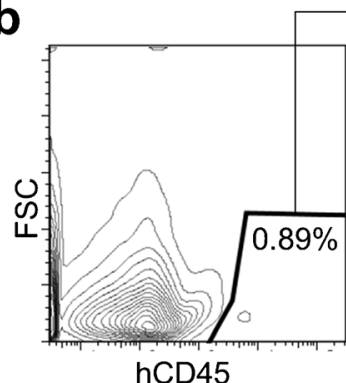

d

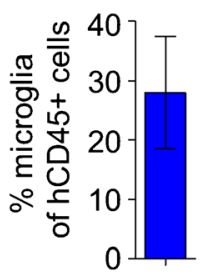

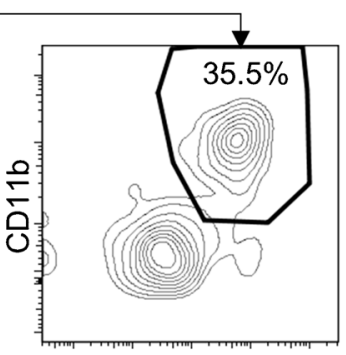

$\mathrm{P} 2 \mathrm{rY} 12$

$\mathbf{e}$

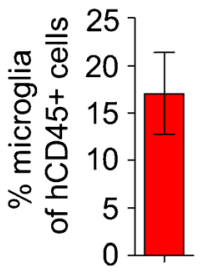

Fig. 1 Human microglia in the brains of humanized mice. a Experimental scheme to create humanized mice using either irradiation or busulfan conditioning. At necropsy, the total glial fraction was isolated using a Percoll gradient, and the human cells and microglia in that fraction identified by flow cytometry using indicated markers. b Representative flow cytometry analysis of human microglia (hCD45+/CD11b+/ $\mathrm{P} 2 \mathrm{rY} 12+)$ in an irradiated mouse. $\mathbf{c}$ Representative flow cytometry plot

C
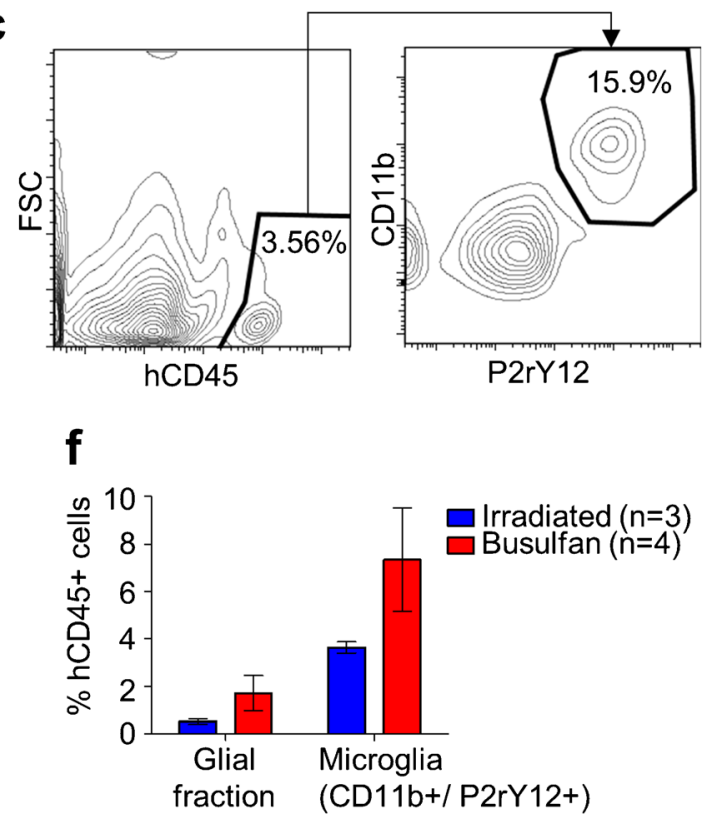

analysis of human microglia in a mouse conditioned with busulfan. d Quantification of human microglia in $n=3$ irradiated mice. e Quantification of human microglia in $n=4$ busulfan-conditioned mice. f Comparison of levels of human cell (hCD45+) contribution in the glial fraction, and the total microglial population, in irradiated versus busulfanconditioned mice 


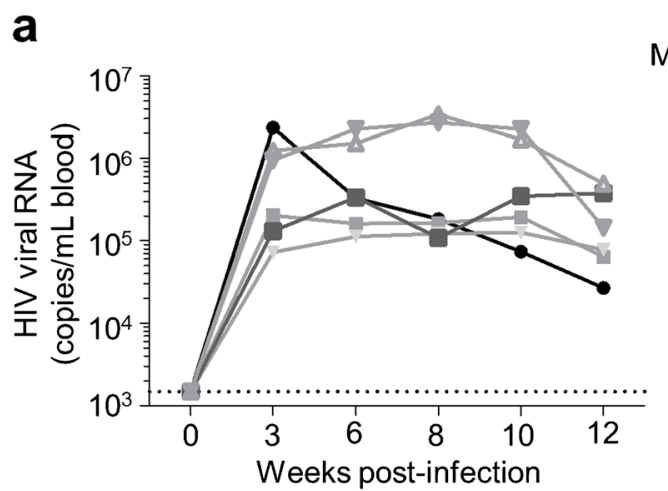

Fig. 2 HIV infection of microglia. a Neonate-engrafted humanized mice were infected with HIV strain JRCSF-HA $(n=6)$. Virus levels in the blood were measured over time. Dotted line represents limit of detection of assay $=1.5 \times 10^{3}$. b After 12 weeks post-infection, glial cells from

\section{Identification of selective inducers of HIV proviral latency}

Although significant progress has been made in our understanding of the mechanisms promoting HIV latency in T cells, the mechanisms that could contribute to latency in microglia are less well understood (Alvarez-Carbonell et al. 2017). To identify genes involved in maintaining HIV latency in microglia, we performed a genome-wide shRNA library screen using CHME-5/HIV cells. CHME-5/HIV cells are a rat microglial cell line that contains a single integrated copy of a defective reporter HIV genome, in which Nef has been replaced by a short-lived GFP reporter (d2EGFP). The HIV genome is latent, but can be reactivated to express GFP by agents such as TNF- $\alpha$ or trichostatin A (Wires et al. 2012).

The shRNA screen used a genome-wide lentiviral library from Cellecta, combined with systems biology classifications of the hits, as previously described (Li et al. 2016; Nguyen et al. 2017). Briefly, the CHME-5/HIV cells were transduced with the shRNA library vectors, and $\mathrm{GFP}^{+}$cells were selected by cell sorting. The target genes of the shRNAs leading to reactivation determined by sequencing (Li et al. 2016; Nguyen et al. 2017). As summarized in Fig. 3a, members of the CoREST repression complex, including HDAC2, CTBP1, and CTBP2, were highly ranked "hits" in the screen. These candidates were confirmed by specific shRNA-mediated knockdown of the CoREST protein and its associated cofactors in CHME-5/HIV cells.

To confirm the role of the CoREST repression complex in maintaining HIV latency in microglial cells, we used our recently developed model of HIV latency in human microglia cells (H $\mu$ glia/HIV), clone HC69 (Alvarez-Carbonell et al. 2017; Garcia-Mesa et al. 2017). These cells were derived from immortalized primary human microglia and contain a latent reporter HIV construct that expresses GFP after proviral reactivation. HC69 cells were treated with pharmacological inhibitors that target G9a and GLP, two essential members of the CoREST complex. As shown in Fig. 3b, there was latency-reversing

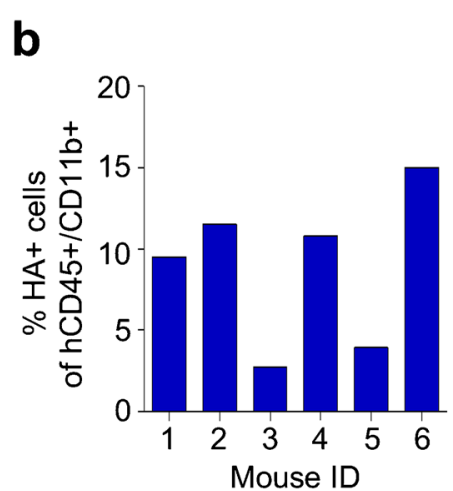

individual mice were analyzed by flow cytometry to quantify the frequency of HIV infection $(\mathrm{HA}+)$ in cells expressing markers of human microglia (hCD45+ CD11b+)

activity by BIX01294 (22.73\% $\left.\mathrm{GFP}^{+}\right)$, which targets G9a/ EHMT2 (Shi et al. 2003) and UNC0638 (26.94\% GFP ${ }^{+}$), which targets the GLPL/G9a (EHMT1/EHMT2) heterodimer (Vedadi et al. 2011). Both compounds by themselves were able to increase GFP expression significantly above basal levels $\left(5.3 \% \mathrm{GFP}^{+}\right)$.

To determine whether the epigenetic latency-reversing factors that we identified were specific for microglia, we tested BIX01294 and UNC0638 on 2D10 cells (Pearson et al. 2008), a latently infected Jurkat T cell line carrying a similar GFP reporter construct. Neither compound reactivated GFP in these cells (Fig. 3d), however, both compounds are weak latency-reversing agents in primary T cells and patient cells (Nguyen et al. 2017).

We also tested the monoamine oxidase (MAO) inhibitor phenelzine. Phenelzine was drawn to our attention because, in addition to it MAO inhibition activity, it has been reported to inhibit another member of the CoREST complex, LSD1 (KDM1) (Culhane et al. 2010; Sakane et al. 2011). We found that phenelzine was a moderate latency-reversing agent in HC69 cells (12.24\% GFP ${ }^{+}$) (Fig. 3b).

To evaluate whether the effect of phenelzine on HIV reactivation was due to its anti-LSD1 (KDM1) activity or its antiMAO activity, we tested a series of highly specific MAO inhibitors or LSD-1 (KDM1) inhibitors. M-30, a specific inhibitor of MAO, reactivated GFP in HC69 cells $\left(23.31 \% \mathrm{GFP}^{+}\right)$while in contrast, the specific LSD1 (KDM1) inhibitors RN-1, GSKLSD1, and SP-2509 had no effect (Fig. 3c). This indicates that the phenelzine-mediated reactivation of latent HIV is due primarily to its anti-MAO activity, possibly due to the increased NF- $\kappa$ B phosphorylation stimulation by phenelzine (Chung et al. 2012). Thus, MAO inhibition clearly provides a potent and selective means to reactivate HIV in microglial cells.

\section{Human microglia isolated from HIV-infected humanized mice can be used to evaluate latency reversal drugs}

The latency-reversing agents that are active in the microglia cell line models of HIV latency can potentially be used 
a

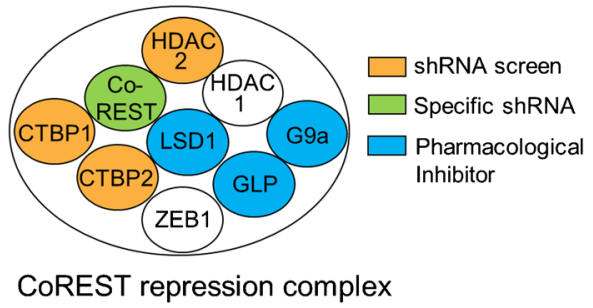

C

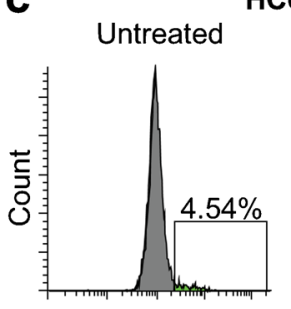

$\mathrm{M}-30$

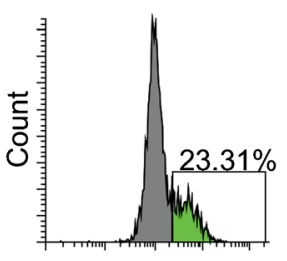

GSK-LSD1

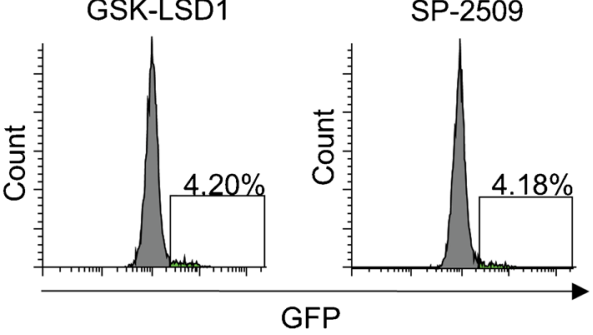

b

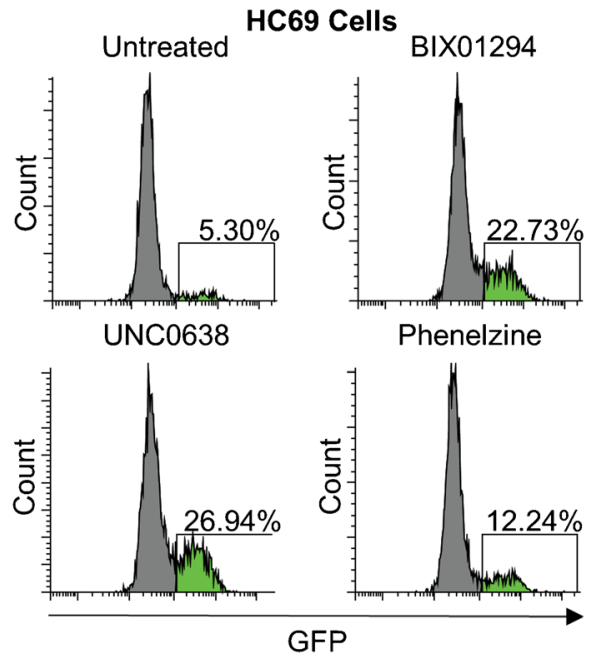

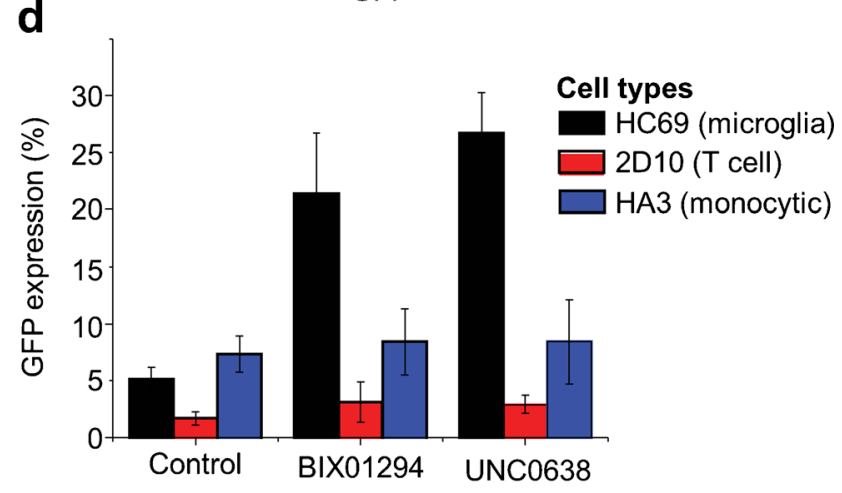

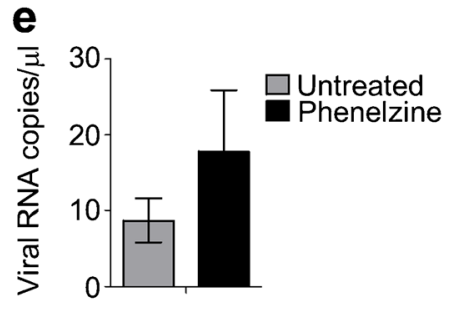

Fig. 3 Inhibition of G9a/EHMT2, GLP/EHMT1, or MAO promotes HIV emergence from latency in microglia. a CHME-5/HIV cells were subjected to genome-wide shRNA screening to identify shRNAs that increased HIV (GFP) expression. Members of the CoREST repressor complex are shown, with the three shRNA target genes with high level hits indicated (orange). The role of CoREST in latency maintenance was also confirmed by specific shRNA knockdown (green). Other members of the complex were analyzed in HC69 cells (see below) using pharmacological inhibitors (blue). b HIV emergence from latency in human microglial HC69 cells, detected by $\mathrm{GFP}^{+}$expression at $16 \mathrm{~h}$ posttreatment using inhibitors BIX01294 (G9a inhibitor), UNC0638 (GLP/ G9a inhibitor), and phenelzine (LSD1 and MAO inhibitor). In the flow

as tools to stimulate HIV production from human microglia infected in vivo in humanized mice. For an initial study, we used phenelzine. Although this compound is not as potent as some of the other MAO inhibitors that we have identified, it is nonetheless highly selective for microglial cells and is an FDA-approved antidepressant with proven bloodbrain barrier penetration.

cytometry plots, $\mathrm{GFP}^{+}$cell populations are colored green, and the percentage of GFP-expressing cells is indicated. $\mathbf{c}$ To determine whether phenelzine activation of HIV latency is due to LSD1 or MAO, HC69 cells were treated with LSD1 inhibitors (phenelzine, RN-1, GSK-LSD1, or SP-2509) or MAO inhibitors (phenelzine or M-30) and analyzed for GFP expression. d Activation of HIV from HC69 cells (microglia latency—black bars), 2D10 cells (T cell latency—red bars), or HA3 cells (monocytic latency - blue bars), treated with the indicated drugs. Error bars represent the standard deviation of three or more experiments. e Glial cells from five individual JRCSF-HA-infected mice were cultured with or without phenelzine for 2 days, and HIV copies in the culture supernatants measured by qRT-PCR. Error bars represent standard error of the mean

We isolated the total glial cell population from 5 JRCSFinfected humanized mice and cultured them ex vivo, with or without phenelzine, for 2 days. HIV released into the supernatant was measured by qRT-PCR of viral RNA. As shown in Fig. 3e, there was an approximately twofold increase in the amount of HIV released from phenelzine-treated cells compared to untreated cells. 
An unusual feature of the reversal of HIV latency is that the induction of Tat leads to an "all or nothing" induction of transcription. When latency is reversed, intermediate levels of HIV expression in those cells are never seen. Therefore, increases in HIV expression invariably correlate with an increase in the number of cells producing HIV (Jadlowsky et al. 2014; Mbonye and Karn 2017; Nguyen et al. 2017). Thus, the enhanced viral production seen after treatment of the glial cell population with phenelzine is consistent with reversal of latency in a subset of the infected microglial cell population (Fig. 3e).

\section{Discussion}

\section{HSC-reconstituted mice harbor human microglia in their brains}

A major cell type in the CNS that supports productive infection by HIV is the microglia, a macrophage-like cell that functions as the primary immune cell of the brain. To facilitate studies of both productive and latent infections of microglia that could contribute to the persistence of HIV in the CNS during ART, we have begun to characterize the human cells present in the brains of HSCtransplanted, HIV-infected humanized mice. We readily detected human cells with markers of microglia in these humanized mice, based on co-expression of CD11b and the more specific microglial marker, P2RY12 (Butovsky et al. 2014). Furthermore, in HIV-infected animals, we detected HIVinfected cells in this fraction (mean $9 \%$ of human microglia).

Despite the macrophage-like properties of microglia, fatetracking studies have shown that they develop from an embryonic lineage, yolk sac erythro-myeloid progenitors, that are distinct from HSC, which derive from the aorta-gonad-mesonephros region (Medvinsky and Dzierzak 1996). Accordingly, it has been debated whether or not HSC can give rise post-natally to microglia (Ginhoux et al. 2013). However, mouse-to-mouse transplant experiments have shown that donor HSC produce cells that are phenotypically indistinguishable from microglia in mice whose resident microglia have been depleted by radiation, chemotherapy, or through microglia-specific expression of a suicide gene (Capotondo et al. 2012; Derecki et al. 2012; Sergijenko et al. 2013; Varvel et al. 2012). Furthermore, injection of human HSC into radiation-treated immune-deficient mice populates the brain with human cells expressing microglial markers (Asheuer et al. 2004). These observations also fit with findings from clinical trials using genetically modified autologous HSC to treat neurological diseases such as ALD, where conditioning allows microglia derived from the engineered HSC to provide enzymatic transcomplementation and clinical benefit (Cartier et al. 2009).

Our characterization of humanized mice also supports the idea that transient depletion of endogenous mouse microglia allows repopulation by human HSC-derived cells. Conditioning using busulfan, which depletes endogenous microglia more than irradiation, nearly doubles microglial cell engraftment in the brains of the mice. This also provides a simple technical advance that makes the humanized mouse model a more effective and practical approach to studies of HIV infection in the brain.

\section{MAO inhibitors specifically reactivate latent HIV in microglia}

We are currently using humanized mice to study whether latently infected microglia can persist in mice treated with ART, and to evaluate whether any such reservoir could be perturbed by compounds that specifically reactivate latent HIV in microglia. We have previously reported that distinct pathways are involved in the activation of latent HIV in microglia, including the TLR3 pathway (Alvarez-Carbonell et al. 2017). We used a shRNA screen in a cell line model of HIV latency to identify microgliaspecific pathways based on the CoREST repressor complex. Pharmacological inhibition of key epigenetics-modifying enzymes in this complex (EHMT1 and EHMT2) led to the specific reactivation of latent $\mathrm{HIV}$ in microglial cells, but not in cell line models of latent HIV in T cells or monocytes. These results are consistent with previous reports that EHMT2 is an important regulator of HIV latency in microglial cell lines (Le Douce et al. 2012; Marban et al. 2007). While phenelzine also acts as a weak inhibitor of the CoREST complex protein LSD-1 (KDM1), we found that it is its ability to inhibit MAO that reversed latency in microglial cells. We then studied whether other MAO inhibitors, such as M-30, could also reactivate HIV and found that they are indeed potent and selective reactivating agents in microglial cells.

The reactivation of latent HIV by specific drugs is being considered as an adjunct to ART that could reduce the latent reservoir through a "shock and kill" approach and thereby allow an HIV cure. Although the major focus in such studies has been on drugs that can activate latent T cells, latent reservoirs in the CNS are likely to become a major barrier to curing HIV (Brew et al. 2015; Darcis et al. 2017; Katlama et al. 2013; Siliciano and Siliciano 2013). Phenelzine is FDA-approved as an antidepressant and has proven blood-brain barrier penetration. Therefore, phenelzine, along with other MAO inhibitors, should become useful tools to reverse HIV latency in the humanized mouse model.

\section{Modeling HIV latency in microglial cells using HSC-reconstituted humanized mice}

We also evaluated the ability of phenelzine to stimulate HIV production from microglia harvested from HIV-infected humanized mice and found that it was able to increase HIV production in these cells approximately twofold. In this experiment, the difference in levels of virus released from unstimulated and phenelzine-stimulated cells was likely minimized because the cells used for this experiment were from 
non-ART-treated mice, which increases the background of HIV production in the untreated cell control. Although we have not yet formally ruled out that this effect of phenelzine is due instead to enhanced production of HIV from productively infected cells, work in cell models has shown that induced cells produce HIV Tat and therefore have a uniformly maximal induction of HIV transcription. Thus, increases in HIV production after latency reversal invariably reflect increases in the number of productive cells (Jadlowsky et al. 2014; Kim et al. 2011; Mbonye et al. 2013; Nguyen et al. 2017). The phenelzine data therefore indicates that a subset of microglia recovered from the reconstituted mice are latently infected and can be reactivated by this drug.

Going forward, we plan to study the effect of various latency reactivators, including pro-inflammatory molecules and inhibitors of repressor complexes, on HIV emergence from latency in microglia harvested from ART-treated animals. We are also expanding the ex vivo studies using sensitive intracellular RNA detection methods to more rigorously demonstrate latency in this system.

\section{Modeling HIV-associated neurocognitive disorders}

HIV-1 replication in the CNS is probably initiated from invading monocytes and then spreads to microglial cells and astrocytes within the brain parenchyma (Churchill et al. 2009; Cosenza et al. 2002; Fischer-Smith et al. 2004; Liu et al. 2004; Takahashi et al. 1996; Wiley 2003; Wiley et al. 1986). Definitive evidence that HIV replicates in macrophages within the CNS comes from the observation that HIV-associated dementia (HAD) patients harbor macrophage-tropic HIV-1 variants that grow selectively in the CNS (Gorry et al. 2002; Peters et al. 2004; Rossi et al. 2008; Schnell et al. 2011). A consequence of HIV-1 replication in longer-lived cell types in the brain, such as microglial cells, is that virus in the cerebrospinal fluid (CSF) decays more slowly than virus found in the peripheral circulation after the initiation of therapy (Schnell et al. 2009).

An important contribution to HIV-1 neuropathology is the combined neurotoxic effects of viral proteins and exaggerated inflammatory responses. In vitro studies have demonstrated the toxic effects of the viral proteins gp120 (Kaul and Lipton 2006) and Tat (El-Hage et al. 2011; Li et al. 2009) on neurons. Both in vitro and in vivo studies have shown that immuneactivated, HIV-infected, brain-infiltrating macrophages, and resident microglia, also release high levels of neurotoxic cytokines such as TNF- $\alpha$ and IL-1 $\beta$ (Kaul and Lipton 2006). Cytokine release is also a response to HIV proteins, since exposure of macrophages to intact HIV-1 virions or gp120 induced IL-1 $\beta$ release independently of productive infection (Cheung et al. 2008; Herbein et al. 1994; Merrill et al. 1989).

Importantly, neuronal dysfunction does not correlate with the number of HIV-infected cells or viral antigens in CNS (Glass et al. 1995; Masliah et al. 1997), but rather with elevated inflammatory cytokine levels. Elevated TNF- $\alpha$ mRNA levels in microglia and astrocytes (Glass et al. 1995; Wesselingh et al. 1997) and high levels of IL- $1 \beta$ and TNF- $\alpha$ are seen in the CNS of patients with HAD (Brabers and Nottet 2006; Epstein and Gendelman 1993). Similarly, increased IL6 and IL- 8 levels have also been reported in the brains of HIV1 infected patients (Breen et al. 1990), and several studies show that gp120 also induces IL-6 expression in mixed cultures of human primary brain cells (Yeung et al. 1995) and murine primary mixed glial cell cultures (Kong et al. 1996). A central role for IL-6 in gp120-induced neuroinflammation has been demonstrated using a rat model (Schoeniger-Skinner et al. 2007), where intrathecal administration of gp120 induced the expression of IL- 6 , TNF- $\alpha$, and IL- $1 \beta$.

It is notable that the inflammatory signals correlated with HAND in well-suppressed patients are the same signals that induce latent HIV in microglial cell models (Alvarez-Carbonell et al. 2017). The development of the humanized mouse models described here offers an exciting opportunity to investigate the inter-relationship between HIV latency and chronic inflammatory on the development of neuropathology in vivo.

\section{Methods}

Cell lines Cell lines CHME-5/HIV (microglia), HC69 (microglia), 2D10 (T cell), and HA3 (monocytic) are models of HIV latency, containing a GFP reporter in place of gag in an HIV proviral clone, and expressing GFP only when stimulated (Alvarez-Carbonell et al. 2017; Garcia-Mesa et al. 2017; Pearson et al. 2008; Wires et al. 2012). CHME-5/HIV cells were cultured in DMEM plus 5\% FBS (ThermoFisher Scientific, Carlsbad, CA), HC69 cells in DMEM plus $1 \%$ FBS, 2D10, and HA3 cells in RPMI plus $10 \%$ FBS (ThermoFisher Scientific).

Creation of humanized mice NOD Cg-Prkcd ${ }^{\text {scid }}$ Il2 $\mathrm{rgtm}^{\mathrm{Wjl}}{ }^{\mathrm{Wzz}}$ (NSG) were conditioned using sub-lethal radiation doses of $150 \mathrm{~Gy}$ (neonates) or $250 \mathrm{~Gy}$ (adults), or treated with $35 \mathrm{mg} / \mathrm{kg}$ busulfan (adults) (Alpha Aesar, Haverhill, MA). After $4 \mathrm{~h}$ (irradiation) or $24 \mathrm{~h}$ (busulfan), the mice were injected with $1 \times 10^{6} \mathrm{CD} 34+$ cells, isolated from human fetal liver, as previously described (Holt et al. 2010; Wang et al. 2015). Human cell engraftment levels in the blood were measured in animals from 8 weeks of age using an antibody mix containing human-specific antibodies: anti-hCD3-PE (UCHT1) anti-hCD4-FITC (RPA-T4) and antihCD45-PerCP (2D1) (BD Biosciences, San Jose, CA).

HIV-1 virus production and infection of humanized mice The HIV-1 proviral clone, JRCSF-HA, was generated by inserting an HA epitope-tagged HSA protein into the $v p r$ open reading frame of JRCSF (Koyanagi et al. 1987) and is similar 
to the NL4-3-HSA-HA clone previously published (Ali and Yang 2006). Virus stocks of JRCSF and JRCSF-HA were generated by transient transfection of HEK 293T cells (ATCC, Manassas, VA), using $18 \mu \mathrm{g}$ of plasmid in a $10-\mathrm{cm}$ plate, essentially as described (Cannon et al. 1994). Virus titer (infectious units $/ \mathrm{mL}$ ) was determined by infection of Ghost(3)X4/R5 cells, obtained through the NIH AIDS Reagent Program, Division of AIDS, NIAID, NIH, from Drs. Vineet N. Kewalramani and Dan R. Littman (Morner et al. 1999), as previously described (Cecilia et al. 1998). Humanized mice between ages 12 to 20 weeks, engrafted with at least 30\% human CD45+ cells in the blood, of which at least $10 \%$ were $\mathrm{CD} 3+/ \mathrm{CD} 4+$, were infected with JRCSF or JRCSF-HA, using $500 \mu \mathrm{L}$ intraperitoneal injections containing 5 to $10 \times 10^{5}$ infectious units.

HIV-1 qRT-PCR HIV-1 RNA was extracted from either $50 \mu \mathrm{L}$ of mouse blood, or $100 \mu \mathrm{L}$ cell culture supernatants, using a Qiagen Viral RNA Isolation Kit according to the manufacturer's instructions (Qiagen, Hilden, Germany). qRT PCR was performed using the Taqman RNA-to-CT One Step Kit, according to the manufacturer's instructions (Applied Biosystems, Foster City, CA). Primers used were LTR-F: 5'-GCCTCAATAAAGCT TGCCTTGAG-3' and LTR-R: 5'-GGCGCCACTGCTAG AGATTTTC-3', with a FAM-TAM probe sequence: 5'-AAGT AGTGTGTGCCCGTCTGTTRTKTGACT-3' (Applied Biosystems). Cycling conditions used were 1 cycle of $45^{\circ} \mathrm{C}$ for $35 \mathrm{~min}$, then 43 cycles of 95 and $68^{\circ} \mathrm{C}$ for 1 min each. Standards were 10-fold dilutions of an in-house titered NL4-3 virus stock. Limit of detection (LOD) of the assay is 10 copies, which corresponds to 1500 copies/mL mouse blood or 500 copies $/ \mathrm{mL}$ cell culture supernatant.

Glial cell isolation and flow cytometry Mice were anesthetized with avertin and cardiac perfused with $30-50 \mathrm{~mL}$ PBS to remove lymphocytes and macrophages from the brain. Glial cells were isolated essentially as described (Moussaud and Draheim 2010). Briefly, brains were minced and collagenase/dispase (Roche, Basil, Switzerland) treated for $30 \mathrm{~min}$ at $37^{\circ} \mathrm{C}$ and then DNAse treated (Roche). Cells were washed with PBS and resuspended in $20 \%$ isotonic Percoll (in Hank's balanced saline solution (HBSS) (ThermoFisher Scientific), with HBSS layered on top, and centrifuged for $20 \mathrm{~min}$ at $200 \mathrm{~g}$. The interphase containing myelinated cells was discarded and the pelleted fraction (glial cells) washed with HBSS and immunostained with anti-human CD45PerCP (2D1) (BD Biosciences), anti-CD11b-PE (M1/70) (Biolegend, San Diego, CA) and anti-P2RY12 (Abcam, Cambridge, United Kingdom). For P2RY12 (unconjugated), donkey anti-rabbit Alexa Fluor 488 (ThermoFisher Scientific) was used as a secondary antibody. Flow cytometry analyses were performed using a FACSCanto II (BD Biosciences), with compensation samples created using BD CompBeads (BD
Biosciences). Data were analyzed using FlowJo software V7.6.5 (Treestar, Ashland, OR).

Unbiased human shRNA screening CHME-5/HIV cells were subjected to genome-wide shRNA screening using a human shRNA library packaged in VSV-G pseudotyped lentiviral vectors (Cellecta Inc., Mountain View, CA). The lentiviral library comprises 82,500 shRNAs targeting 15,439 mRNA sequences and carries a puromycin-resistance cassette. Transduced cells were selected in puromycin $(2 \mu \mathrm{g} / \mathrm{mL})$, and GFP-positive cells, which indicate HIV reactivation, selected by FACS. Puromycinresistant/GFP ${ }^{+}$cells were expanded to $1 \times 10^{7}$ cells and subjected to an additional two rounds of $\mathrm{GFP}^{+}$sorting. After the third round of purification/expansion, when nearly $50 \%$ of the cells were constitutively $\mathrm{GFP}^{+}$, genomic DNA was isolated from $4 \times 10^{6}$ cells and used as a template for nested PCR using primers that recognize sequences flanking the unique bar-code sequences in the lentiviral vectors, and which are unique for each shRNA. High throughput deep sequencing was performed on the nested PCR-amplified product and the sequenced bar-codes de-convoluted to their shRNA sequences using the Decipher Deconvolution software (Cellecta Inc.). The shRNAs were then ranked based on their abundance, and classified by Ingenuity Pathway Analysis ${ }^{\mathrm{TM}}$.

Transduction of CHME-5/HIV cells with specific shRNA vectors $10^{5} \mathrm{CHME}-5 / \mathrm{HIV}$ cells were transduced with VSVG-pseudotyped lentiviral vectors expressing scrambled or CoREST specific shRNAs. The shRNAs were inserted in the pLKO.1 backbone and comprised the scrambled nonsilencing GIPZ lentiviral shRNAmir control and CoREST shRNA RHS4533-NM_015156, obtained from Thermo Scientific Open Biosystems. Three days after transduction, drug-resistant cells were selected in medium containing puromycin $(2 \mu \mathrm{g} / \mathrm{mL})$ for at least 7 days. Cell viability and GFP expression were assessed by FACS and fluorescence microscopy, as described below.

Analysis of HIV reactivation in latently infected cell lines Quantification of GFP expression was performed by flow cytometry analysis using a LSR Fortessa instrument, the FACSDiva software (BD, NJ) for data collection, and the WinList 3D software for data analysis. Prior to analysis, CHME-5/HIV and HC69 cells (adherent) were trypsinized, collected, and resuspended in $300 \mu \mathrm{L}$ of cold PBS, while the suspension cells 2D10 and HA3 were centrifuged, and pellets resuspended in $300 \mu \mathrm{L}$ of PBS. Drug treatments of HIVlatently infected $\mathrm{CHME}-5 / \mathrm{HIV}, \mathrm{HC} 69, \mathrm{HA} 3$, and 2D10 cells were typical for $16 \mathrm{~h}$, with the following concentrations: $4 \mu \mathrm{M}$ BIX01294 (Sigma-Aldrich B9311), 3 «M UNC0638 (SigmaAldrich U4885), $500 \mu \mathrm{M}$ phenelzine (Sigma-Aldrich P6777), 100 MM M-30 (Sigma-Aldrich SML0128), 100 M RN-1 
(Tocris 4977), $100 \mu \mathrm{M}$ GSK-LSD1 (Sigma-Aldrich SML1072), and $2 \mu \mathrm{M}$ SP-2509 (Cayman Chemical 15487).

Ex vivo activation of HIV in glial cell fraction Glial cells $\left(5 \times 10^{5}\right)$ isolated from HIV-infected humanized mice were cultured in DMEM-F/12 (ThermoFisher Scientific), 10\% FBS and penicillin/streptomycin, with or without $5 \mu \mathrm{M}$ phenelzine (Sigma). After 2 days, HIV was quantified from the supernatants via RNA extraction and qRT-PCR, as described above.

Acknowledgments We thank the CWRU Genomics Core for RNA sequencing services, and the CWRU/UH Center for AIDS Research (P30 AI36219) for flow cytometry services. This work was supported by NIH grants R01 DA036171 and R01 DA043159 (JK), R01 MH113457 (PC), and the American Foundation for AIDS Research (amfAR) 108904-56-RGRL (PC).

\section{Compliance with ethical standards}

Conflict of interest The authors declare that they have no conflict of interest.

Open Access This article is distributed under the terms of the Creative Commons Attribution 4.0 International License (http:// creativecommons.org/licenses/by/4.0/), which permits unrestricted use, distribution, and reproduction in any medium, provided you give appropriate credit to the original author(s) and the source, provide a link to the Creative Commons license, and indicate if changes were made.

\section{References}

Ali A, Yang OO (2006) A novel small reporter gene and HIV-1 fitness assay. J Virol Methods 133(1):41-47. https://doi.org/10.1016/j. jviromet.2005.10.016

Alvarez-Carbonell D, Garcia-Mesa Y, Milne S, Das B, Dobrowolski C, Rojas R, Karn J (2017) Toll-like receptor 3 activation selectively reverses HIV latency in microglial cells. Retrovirology 14(1):9. https://doi.org/10.1186/s12977-017-0335-8

Asheuer M, Pflumio F, Benhamida S, Dubart-Kupperschmitt A, Fouquet F, Imai Y, Aubourg P, Cartier N (2004) Human CD34+ cells differentiate into microglia and express recombinant therapeutic protein. Proc Natl Acad Sci U S A 101(10):3557-3562. https://doi.org/10. 1073/pnas.0306431101

Barton K, Winckelmann A, Palmer S (2016) HIV-1 reservoirs during suppressive therapy. Trends Microbiol 24(5):345-355. https://doi. org/10.1016/j.tim.2016.01.006

Bednar MM, Sturdevant CB, Tompkins LA, Arrildt KT, Dukhovlinova E, Kincer LP, Swanstrom R (2015) Compartmentalization, viral evolution, and viral latency of HIV in the CNS. Curr HIV/AIDS Rep 12(2):262-271. https://doi.org/10.1007/s11904-015-0265-9

Bennett ML, Bennett FC, Liddelow SA, Ajami B, Zamanian JL, Fernhoff NB, Mulinyawe SB, Bohlen CJ, Adil A, Tucker A, Weissman IL, Chang EF, Li G, Grant GA, Hayden Gephart MG, Barres BA (2016) New tools for studying microglia in the mouse and human CNS. Proc Natl Acad Sci U S A 113(12):E1738-E1746. https://doi.org/ 10.1073/pnas. 1525528113

Boritz EA, Darko S, Swaszek L, Wolf G, Wells D, Wu X, Henry AR, Laboune F, Hu J, Ambrozak D, Hughes MS, Hoh R, Casazza JP, Vostal A, Bunis D, Nganou-Makamdop K, Lee JS, Migueles SA,
Koup RA, Connors M, Moir S, Schacker T, Maldarelli F, Hughes SH, Deeks SG, Douek DC (2016) Multiple origins of virus persistence during natural control of HIV infection. Cell 166(4):1004 1015. https://doi.org/10.1016/j.cell.2016.06.039

Boska MD, Dash PK, Knibbe J, Epstein AA, Akhter SP, Fields N, High R, Makarov E, Bonasera S, Gelbard HA, Poluektova LY, Gendelman HE1, Gorantla S (2014) Associations between brain microstructures, metabolites, and cognitive deficits during chronic HIV-1 infection of humanized mice. Mol Neurodegener 9:58. https://doi.org/10.1186/1750-1326-9-58

Brabers NA, Nottet HS (2006) Role of the pro-inflammatory cytokines TNF- $\alpha$ and IL- $1 \beta$ in HIV-associated dementia. Eur J Clin Investig 36(7):447-458. https://doi.org/10.1111/j.1365-2362.2006.01657.x

Breen EC, Rezai AR, Nakajima K, Beall GN, Mitsuyasu RT, Hirano T, Kishimoto T, Martinez-Maza O (1990) Infection with HIV is associated with elevated IL-6 levels and production. J Immunol 144(2):480-484

Brew BJ, Robertson K, Wright EJ, Churchill M, Crowe SM, Cysique LA, Deeks S, Garcia JV, Gelman B, Gray LR, Johnson T, Joseph J, Margolis DM, Mankowski JL, Spencer B (2015). HIV eradication symposium: will the brain be left behind? J Neurovirol 21(3):322334. https://doi.org/10.1007/s13365-015-0322-6

Butovsky O, Jedrychowski MP, Moore CS, Cialic R, Lanser AJ, Gabriely G, Koeglsperger T, Dake B, Wu PM, Doykan CE, Fanek Z, Liu L, Chen Z, Rothstein JD, Ransohoff RM, Gygi SP, Antel JP, Weiner HL (2014) Identification of a unique TGF-beta-dependent molecular and functional signature in microglia. Nat Neurosci 17(1):131-143. https://doi.org/10.1038/nn.3599

Cannon PM, Wilson W, Byles E, Kingsman SM, Kingsman AJ (1994) Human immunodeficiency virus type 1 integrase: effect on viral replication of mutations at highly conserved residues. J Virol 68(8):4768-4775

Capotondo A, Milazzo R, Politi LS, Quattrini A, Palini A, Plati T, Merella S, Nonis A, di Serio C, Montini E, Naldini L, Biffi A (2012) Brain conditioning is instrumental for successful microglia reconstitution following hematopoietic stem cell transplantation. Proc Natl Acad Sci U S A 109(37):15018-15023. https://doi.org/10.1073/pnas.1205858109

Cartier N, Hacein-Bey-Abina S, Bartholomae CC, Veres G, Schmidt M, Kutschera I, Vidaud M, Abel U, Dal-Cortivo L, Caccavelli L, Mahlaoui N, Kiermer V, Mittelstaedt D, Bellesme C, Lahlou N, Lefrere F, Blanche S, Audit M, Payen E, Leboulch P, l'Homme B, Bougneres P, Von Kalle C, Fischer A, Cavazzana-Calvo M, Aubourg P (2009) Hematopoietic stem cell gene therapy with a lentiviral vector in X-linked Adrenoleukodystrophy. Science 326(5954):818-823. https://doi.org/10.1126/science.1171242

Cecilia D, Kewalramani VN, O'Leary J, Volsky B, Nyambi P, Burda S, Xu S, Littman DR, Zolla-Pazner S (1998) Neutralization profiles of primary human immunodeficiency virus type 1 isolates in the context of coreceptor usage. J Virol 72(9):6988-6996

Cenker JJ, Stultz RD, McDonald D (2017). Brain microglial cells are highly susceptible to HIV-1 infection and spread. AIDS Res Hum Retroviruses 33(11):1155-1165. https://doi.org/10.1089/AID.2017.0004

Cheung R, Ravyn V, Wang L, Ptasznik A, Collman RG (2008) Signaling mechanism of HIV-1 gp120 and virion-induced IL-1 $\beta$ release in primary human macrophages. J Immunol 180(10):6675-6684. https://doi.org/10.4049/jimmunol.180.10.6675

Chung HS, Kim H, Bae H (2012) Phenelzine (monoamine oxidase inhibitor) increases production of nitric oxide and proinflammatory cytokines via the NF-KB pathway in lipopolysaccharide-activated microglia cells. Neurochem Res 37(10):2117-2124. https://doi.org/10. 1007/s11064-012-0833-y

Churchill MJ, Gorry PR, Cowley D, Lal L, Sonza S, Purcell DF, Thompson KA, Gabuzda D, McArthur JC, Pardo CA, Wesselingh SL (2006) Use of laser capture microdissection to detect integrated HIV-1 DNA in macrophages and astrocytes from autopsy brain tissues. J Neuro-Oncol 12:146-152 
Churchill MJ, Wesselingh SL, Cowley D, Pardo CA, McArthur JC, Brew BJ, Gorry PR (2009) Extensive astrocyte infection is prominent in human immunodeficiency virus-associated dementia. Ann Neurol 66(2):253-258. https://doi.org/10.1002/ana.21697

Cosenza MA, Zhao ML, Si Q, Lee SC (2002) Human brain parenchymal microglia express CD14 and CD45 and are productively infected by HIV-1 in HIV-1 encephalitis. Brain Pathol 12(4):442-455

Culhane JC, Wang D, Yen PM, Cole PA (2010) Comparative analysis of small molecules and histone substrate analogues as LSD1 lysine demethylase inhibitors. J Am Chem Soc 132(9):3164-3176. https://doi.org/10.1021/ja909996p

Dahl V, Gisslen M, Hagberg L, Peterson J, Shao W, Spudich S, Price RW, Palmer S (2014) An example of genetically distinct HIV type 1 variants in cerebrospinal fluid and plasma during suppressive therapy. J Infect Dis 209(10):1618-1622. https://doi.org/10.1093/infdis/jit805

Darcis G, Van Driessche B, Van Lint C (2017) HIV latency: should we shock or lock? Trends Immunol 38(3):217-228. https://doi.org/10. 1016/j.it.2016.12.003

Dash PK, Gorantla S, Gendelman HE, Knibbe J, Casale GP, Makarov E, Epstein AA, Gelbard HA, Boska MD, Poluektova LY (2011) Loss of neuronal integrity during progressive HIV-1 infection of humanized mice. J Neurosci. 31(9):3148-57. https://doi.org/10.1523/ JNEUROSCI.5473-10.2011

Derecki NC, Cronk JC, Lu ZJ, Xu E, Abbott SBG, Guyenet PG, Kipnis J (2012) Wild-type microglia arrest pathology in a mouse model of Rett syndrome. Nature 484:105-+

Desplats P, Dumaop W, Smith D, Adame A, Everall I, Letendre S, Ellis R, Cherner M, Grant I, Masliah E (2013) Molecular and pathologic insights from latent HIV-1 infection in the human brain. Neurology 80(15):1415-1423. https://doi.org/10.1212/WNL. 0b013e31828c2e9e

Eglitis MA, Mezey E (1997) Hematopoietic cells differentiate into both microglia and macroglia in the brains of adult mice. Proc Natl Acad Sci U S A 94(8):4080-4085. https://doi.org/10.1073/pnas.94.8.4080

El-Hage N, Podhaizer EM, Sturgill J, Hauser KF (2011) Toll-like receptor expression and activation in Astroglia: differential regulation by HIV-1 Tat, gp120, and morphine. Immunol Investig 40(5):498522. https://doi.org/10.3109/08820139.2011.561904

Epstein LG, Gendelman HE (1993) Human immunodeficiency virus type 1 infection of the nervous system: pathogenetic mechanisms. Ann Neurol 33(5):429-436. https://doi.org/10.1002/ana.410330502

Fischer-Smith T, Croul S, Adeniyi A, Rybicka K, Morgello S, Khalili K, Rappaport J (2004) Macrophage/microglial accumulation and proliferating cell nuclear antigen expression in the central nervous system in human immunodeficiency virus encephalopathy. Am J Pathol 164(6): 2089-2099. https://doi.org/10.1016/S0002-9440(10)63767-4

Fois AF, Brew BJ (2015) The potential of the CNS as a reservoir for HIV1 infection: implications for HIV eradication. Curr Hiv/Aids Rep 12(2):299-303. https://doi.org/10.1007/s11904-015-0257-9

Garcia-Mesa Y, Jay TR, Checkley MA, Luttge B, Dobrowolski C, Valadkhan S, Landreth GE, Karn J, Alvarez-Carbonell D (2017) Immortalization of primary microglia: a new platform to study HIV regulation in the central nervous system. J Neuro-Oncol 23:47-66

Garrido C, Margolis DM (2015) Translational challenges in targeting latent HIV infection and the CNS reservoir problem. J NeuroOncol 21:222-226

Gianella S, Kosakovsky Pond SL, Oliveira MF, Scheffler K, Strain MC, De la Torre A, Letendre S, Smith DM, Ellis RJ (2016) Compartmentalized HIV rebound in the central nervous system after interruption of antiretroviral therapy. Virus Evol 2:vew020

Ginhoux F, Lim S, Hoeffel G, Low D, Huber T (2013) Origin and differentiation of microglia. Front Cell Neurosci 7:45. https://doi.org/10. 3389/fncel.2013.00045

Glass JD, Fedor H, Wesselingh SL, McArthur JC (1995) Immunocytochemical quantitation of human immunodeficiency virus in the brain: correlations with dementia. Ann Neurol 38(5): 755-762. https://doi.org/10.1002/ana.410380510

Gorantla S, Makarov E, Finke-Dwyer J, Castanedo A, Holguin A, Gebhart CL, Gendelman HE, Poluektova L (2010) Links between progressive HIV-1 infection of humanized mice and viral neuropathogenesis. Am J Pathol 177(6):2938-2949. https://doi. org/10.2353/ajpath.2010.100536

Gorry PR, Ong C, Thorpe J, Bannwarth S, Thompson KA, Gatignol A, Vesselingh SL, Purcell DF (2003) Astrocyte infection by HIV-1: mechanisms of restricted virus replication, and role in the pathogenesis of HIV-1-associated dementia. Curr HIV Res 1(4):463-473. https://doi.org/10.2174/1570162033485122

Gorry PR, Taylor J, Holm GH, Mehle A, Morgan T, Cayabyab M, Farzan M, Wang H, Bell JE, Kunstman KJ, Moore JP, Wolinsky SM, Gabuzda D (2002) Increased CCR5 affinity and reduced CCR5/ CD4 dependence of a neurovirulent primary human immunodeficiency virus type 1 isolate. J Virol 76(12):6277-6292. https://doi. org/10.1128/JVI.76.12.6277-6292.2002

Hellmuth J, Valcour V, Spudich S (2015) CNS reservoirs for HIV: implications for eradication. J Virus Erad 1(2):67-71

Herbein G, Keshav S, Collin M, Montaner LJ, Gordon S (1994) HIV-1 induces tumour necrosis factor and IL-1 gene expression in primary human macrophages independent of productive infection. Clin Exp Immunol 95(3):442-449

Holt N, Wang J, Kim K, Friedman G, Wang X, Taupin V, Crooks GM, Kohn DB, Gregory PD, Holmes MC, Cannon PM (2010) Human hematopoietic stem/progenitor cells modified by zinc-finger nucleases targeted to CCR5 control HIV-1 in vivo. Nat Biotechnol 28(8): 839-847. https://doi.org/10.1038/nbt.1663

Honeycutt JB, Sheridan PA, Matsushima GK, Garcia JV (2015) Humanized mouse models for HIV-1 infection of the CNS. J Neuro-Oncol 21:301-309

Honeycutt JB, Wahl A, Baker C, Spagnuolo RA, Foster J, Zakharova O, Wietgrefe S, Caro-Vegas C, Madden V, Sharpe G, Haase AT, Eron JJ, Garcia JV (2016) Macrophages sustain HIV replication in vivo independently of T cells. J Clin Invest 126(4):1353-66. https://doi. org/10.1172/JCI84456. Epub 2016 Mar

Jadlowsky JK, Wong JY, Graham AC, Dobrowolski C, Devor RL, Adams MD, Fujinaga K, Karn J (2014) The negative elongation factor (NELF) is required for the maintenance of proviral latency but does not induce promoter proximal pausing of RNAP II on the HIV LTR. Mol Cell Biol 34(11):1911-1928. https://doi.org/10. 1128/MCB.01013-13

Jordan CA, Watkins BA, Kufta C, Dubois-Dalcq M (1991) Infection of brain microglial cells by human immunodeficiency virus type 1 is CD4 dependent. J Virol 65(2):736-742

Katlama C, Deeks SG, Autran B, Martinez-Picado J, van Lunzen J, Rouzioux C, Miller M, Vella S, Schmitz JE, Ahlers J, Richman DD, Sekaly RP (2013). Barriers to a cure for HIV: new ways to target and eradicate HIV-1 reservoirs. Lancet 381(9883):21092117. https://doi.org/10.1016/S0140-6736(13)60104-X

Kaul M, Lipton SA (2006) Mechanisms of neuronal injury and death in HIV-1 associated dementia. Curr HIV Res 4(3):307-318. https://doi. org/10.2174/157016206777709384

Kim YK, Mbonye U, Hokello J, Karn J (2011) T-cell receptor signaling enhances transcriptional elongation from latent HIV proviruses by activating P-TEFb through an ERK-dependent pathway. J Mol Biol 410(5):896-916. https://doi.org/10.1016/j.jmb.2011.03.054

Kong LY, Wilson BC, McMillian MK, Bing G, Hudson PM, Hong JS (1996) The effects of the HIV-1 envelope protein gp120 on the production of nitric oxide and proinflammatory cytokines in mixed glial cell cultures. Cell Immunol 172(1):77-83. https://doi.org/10. 1006/cimm.1996.0217

Koyanagi Y, Miles S, Mitsuyasu RT, Merrill JE, Vinters HV, Chen IS (1987) Dual infection of the central nervous system by AIDS viruses 
with distinct cellular tropisms. Science 236(4803):819-822. https:// doi.org/10.1126/science.3646751

Le Douce V, Colin L, Redel L, Cherrier T, Herbein G, Aunis D, Rohr O, Van Lint C, Schwartz C (2012) LSD1 cooperates with CTIP2 to promote HIV-1 transcriptional silencing. Nucleic Acids Res 40(5): 1904-1915. https://doi.org/10.1093/nar/gkr857

Li Q, Karim AF, Ding X, Das B, Dobrowolski C, Gibson RM, QuinonesMateu ME, Karn J, Rojas RE (2016) Novel high throughput pooled shRNA screening identifies NQO1 as a potential drug target for host directed therapy for tuberculosis. Sci Rep 6(1):27566. https://doi. org $/ 10.1038 /$ srep27566

Li W, Li G, Steiner J, Nath A (2009) Role of Tat protein in HIV neuropathogenesis. Neurotox Res 16(3):205-220. https://doi.org/ 10.1007/s12640-009-9047-8

Liu Y, Liu H, Kim BO, Gattone VH, Li J, Nath A, Blum J, He JJ (2004) CD4-independent infection of astrocytes by human immunodeficiency virus type 1: requirement for the human mannose receptor. J Virol 78(8):4120-4133. https://doi.org/10.1128/JVI.78.8.41204133.2004

Marban C, Suzanne S, Dequiedt F, de Walque S, Redel L, Van Lint C, Aunis D, Rohr O (2007) Recruitment of chromatin-modifying enzymes by CTIP2 promotes HIV-1 transcriptional silencing. EMBO J 26(2):412-423. https://doi.org/10.1038/sj.emboj.7601516

Masliah E, Heaton RK, Marcotte TD, Ellis RJ, Wiley CA, Mallory M, Achim CL, McCutchan JA, Nelson JA, Atkinson JH, Grant I (1997) Dendritic injury is a pathological substrate for human immunodeficiency virus-related cognitive disorders. HNRC group. The HIV neurobehavioral research center. Ann Neurol 42(6):963-972. https://doi.org/10.1002/ana.410420618

Mbonye U, Karn J (2017) The molecular basis for human immunodeficiency virus latency. Annu Rev Virol 4(1):261-285. https://doi.org/ 10.1146/annurev-virology-101416-041646

Mbonye UR, Gokulrangan G, Datt M, Dobrowolski C, Cooper M, Chance MR, Karn J (2013) Phosphorylation of CDK9 at Ser175 enhances HIV transcription and is a marker of activated P-TEFb in CD4(+) T lymphocytes. PLoS Pathog 9(5):e1003338. https://doi. org/10.1371/journal.ppat.1003338

Medvinsky A, Dzierzak E (1996) Definitive hematopoiesis is autonomously initiated by the AGM region. Cell 86(6):897-906. https:// doi.org/10.1016/S0092-8674(00)80165-8

Merrill JE, Koyanagi Y, Chen IS (1989) Interleukin-1 and tumor necrosis factor alpha can be induced from mononuclear phagocytes by human immunodeficiency virus type 1 binding to the CD4 receptor. J Virol 63(10):4404-4408

Messam CA, Major EO (2000) Stages of restricted HIV-1 infection in astrocyte cultures derived from human fetal brain tissue. J NeuroOncol 6(Suppl 1):S90-S94

Morner A, Bjorndal A, Albert J, Kewalramani VN, Littman DR, Inoue R, Thorstensson R, Fenyo EM, Bjorling E (1999) Primary human immunodeficiency virus type 2 (HIV-2) isolates, like HIV-1 isolates, frequently use CCR5 but show promiscuity in coreceptor usage. J Virol 73(3):2343-2349

Moussaud S, Draheim HJ (2010) A new method to isolate microglia from adult mice and culture them for an extended period of time. $\mathrm{J}$ Neurosci Methods 187(2):243-253. https://doi.org/10.1016/j. jneumeth.2010.01.017

Nguyen K, Das B, Dobrowolski C, Karn J (2017) Multiple histone lysine methyltransferases are required for the establishment and maintenance of HIV-1 latency. MBio 8(1):e00133-e00117. https://doi. org/10.1128/mBio.00133-17

Pearson R, Kim YK, Hokello J, Lassen K, Friedman J, Tyagi M, Karn J (2008) Epigenetic silencing of human immunodeficiency virus (HIV) transcription by formation of restrictive chromatin structures at the viral long terminal repeat drives the progressive entry of HIV into latency. J Virol 82(24):12291-12303. https://doi.org/10.1128/ JVI.01383-08
Persidsky Y, Limoges J, McComb R, Bock P, Baldwin T, Tyor W, Patil A, Nottet HS, Epstein L, Gelbard H, Flanagan E, Reinhard J, Pirruccello SJ, Gendelman HE (1996) Human immunodeficiency virus encephalitis in SCID mice. Am J Pathol 149(3):1027-1053

Peters PJ, Bhattacharya J, Hibbitts S, Dittmar MT, Simmons G, Bell JE, Simmonds P, Clapham PR (2004) Biological analysis of human immunodeficiency virus type $1 \mathrm{R} 5$ envelopes amplified from brain and lymph node tissues of AIDS patients with neuropathology reveals two distinct tropism phenotypes and identifies envelopes in the brain that confer an enhanced tropism and fusigenicity for macrophages. J Virol 78(13):6915-6926. https://doi.org/10.1128/JVI.78. 13.6915-6926.2004

Poluektova L, Gorantla S, Faraci J, Birusingh K, Dou H, Gendelman HE (2004) Neuroregulatory events follow adaptive immune-mediated elimination of HIV-1-infected macrophages: studies in a murine model of viral encephalitis. J Immunol 172(12):7610-7617. https://doi.org/10.4049/jimmunol.172.12.7610

Poluektova LY, Munn DH, Persidsky Y, Gendelman HE (2002) Generation of cytotoxic T cells against virus-infected human brain macrophages in a murine model of HIV-1 encephalitis. J Immunol 168(8):3941-3949. https://doi.org/10.4049/jimmunol.168.8.3941

Potula R, Poluektova L, Knipe B, Chrastil J, Heilman D, Dou H, Takikawa O, Munn DH, Gendelman HE, Persidsky Y (2005) Inhibition of indoleamine 2,3-dioxygenase (IDO) enhances elimination of virus-infected macrophages in an animal model of HIV-1 encephalitis. Blood 106(7):2382-2390. https://doi.org/10.1182/ blood-2005-04-1403

Rossi F, Querido B, Nimmagadda M, Cocklin S, Navas-Martin S (2008) The V1-V3 region of a brain-derived HIV-1 envelope glycoprotein determines macrophage tropism, low CD4 dependence, increased fusogenicity and altered sensitivity to entry inhibitors. Retrovirology 5(1):89. https://doi.org/10.1186/1742-4690-5-89

Sakane N, Kwon HS, Pagans S, Kaehlcke K, Mizusawa Y, Kamada M, Lassen KG, Chan J, Greene WC, Schnoelzer M, Ott M (2011) Activation of HIV transcription by the viral Tat protein requires a demethylation step mediated by lysine-specific demethylase 1 (LSD1/KDM1). PLoS Pathog 7(8):e1002184. https://doi.org/10. 1371/journal.ppat.1002184

Schnell G, Joseph S, Spudich S, Price RW, Swanstrom R (2011) HIV-1 replication in the central nervous system occurs in two distinct cell types. PLoS Pathog 7(10):e1002286. https://doi.org/10.1371/ journal.ppat.1002286

Schnell G, Spudich S, Harrington P, Price RW, Swanstrom R (2009) Compartmentalized human immunodeficiency virus type 1 originates from long-lived cells in some subjects with HIV-1-associated dementia. PLoS Pathog 5(4):e1000395. https://doi.org/10.1371/ journal.ppat. 1000395

Schoeniger-Skinner DK, Ledeboer A, Frank MG, Milligan ED, Poole S, Martin D, Maier SF, Watkins LR (2007) Interleukin-6 mediates lowthreshold mechanical allodynia induced by intrathecal HIV-1 envelope glycoprotein gp120. Brain Behav Immun 21(5):660-667. https://doi.org/10.1016/j.bbi.2006.10.010

Sergijenko A, Langford-Smith A, Liao AY, Pickford CE, McDermott J, Nowinski G, Langford-Smith KJ, Merry CLR, Jones SA, Wraith JE, Wynn RF, Wilkinson FL, Bigger BW (2013) Myeloid/microglial driven autologous hematopoietic stem cell gene therapy corrects a Neuronopathic lysosomal disease. Mol Ther 21(10):1938-1949. https://doi.org/10.1038/mt.2013.141

Shi Y, Sawada J, Sui G, el Affar B, Whetstine JR, Lan F, Ogawa H, Luke MP, Nakatani Y (2003) Coordinated histone modifications mediated by a CtBP co-repressor complex. Nature 422(6933):735-738. https://doi.org/10.1038/nature01550

Siliciano JD, Siliciano RF (2013) HIV-1 eradication strategies: design and assessment. Curr Opin HIV AIDS 8(4):318-325. https://doi.org/10. 1097/COH.0b013e328361eaca 
Spivak AM, Planelles V (2016) HIV-1 eradication: early trials (and tribulations). Trends Mol Med 22(1):10-27. https://doi.org/10.1016/j. molmed.2015.11.004

Takahashi K, Wesselingh SL, Griffin DE, McArthur JC, Johnson RT, Glass JD (1996) Localization of HIV-1 in human brain using polymerase chain reaction/in situ hybridization and immunocytochemistry. Ann Neurol 39(6):705-711. https://doi.org/10.1002/ana. 410390606

Thompson KA, Cherry CL, Bell JE, McLean CA (2011) Brain cell reservoirs of latent virus in presymptomatic HIV-infected individuals. Am J Pathol 179(4):1623-1629. https://doi.org/10.1016/j.ajpath. 2011.06.039

Tyor WR, Power C, Gendelman HE, Markham RB (1993) A model of human immunodeficiency virus encephalitis in scid mice. Proc Natl Acad Sci U S A 90(18):8658-8662. https://doi.org/10.1073/pnas. 90.18 .8658

Varvel NH, Grathwohl SA, Baumann F, Liebig C, Bosch A, Brawek B, Thal DR, Charo IF, Heppner FL, Aguzzi A, Garaschuk O, Ransohoff RM, Jucker M (2012) Microglial repopulation model reveals a robust homeostatic process for replacing CNS myeloid cells. Proc Natl Acad Sci U S A 109(44):18150-18155. https:// doi.org/10.1073/pnas.1210150109

Vedadi M, Barsyte-Lovejoy D, Liu F, Rival-Gervier S, Allali-Hassani A, Labrie V, Wigle TJ, Dimaggio PA, Wasney GA, Siarheyeva A, Dong A, Tempel W, Wang SC, Chen X, Chau I, Mangano TJ, Huang XP, Simpson CD, Pattenden SG, Norris JL, Kireev DB, Tripathy A, Edwards A, Roth BL, Janzen WP, Garcia BA, Petronis A, Ellis J, Brown PJ, Frye SV, Arrowsmith CH, Jin J (2011) A chemical probe selectively inhibits G9a and GLP methyltransferase activity in cells. Nat Chem Biol 7(8):566-574. https:// doi.org/10.1038/nchembio.599

Wang J, Exline CM, DeClercq JJ, Llewellyn GN, Hayward SB, Li PW, Shivak DA, Surosky RT, Gregory PD, Holmes MC, Cannon PM (2015) Homology-driven genome editing in hematopoietic stem and progenitor cells using ZFN mRNA and AAV6 donors. Nat Biotechnol 33(12):1256-1263. https://doi.org/10.1038/nbt.3408

Wesselingh SL, Takahashi K, Glass JD, McArthur JC, Griffin JW, Griffin DE (1997) Cellular localization of tumor necrosis factor mRNA in neurological tissue from HIV-infected patients by combined reverse transcriptase/polymerase chain reaction in situ hybridization and immunohistochemistry. J Neuroimmunol 74(1-2):1-8. https://doi. org/10.1016/S0165-5728(96)00160-9

Wiley CA (2003) Detection of HIV-1 DNA in microglia/macrophages, astrocytes and neurons isolated from brain tissue with HIV-1 encephalitis by laser capture microdissection. Brain Pathol 13(3):415-416

Wiley CA, Schrier RD, Nelson JA, Lampert PW, Oldstone MB (1986) Cellular localization of human immunodeficiency virus infection within the brains of acquired immune deficiency syndrome patients. Proc Natl Acad Sci U S A 83(18):7089-7093. https://doi.org/10. 1073/pnas.83.18.7089

Wilkinson FL, Sergijenko A, Langford-Smith KJ, Malinowska M, Wynn RF, Bigger BW (2013) Busulfan conditioning enhances engraftment of hematopoietic donor-derived cells in the brain compared with irradiation. Mol Ther 21(4):868-876. https://doi.org/10.1038/mt.2013.29

Wires ES, Alvarez D, Dobrowolski C, Wang Y, Morales M, Karn J, Harvey BK (2012) Methamphetamine activates nuclear factor kappa-light-chain-enhancer of activated B cells (NF-KB) and induces human immunodeficiency virus (HIV) transcription in human microglial cells. J Neurovirol 18(5):400-410. https://doi.org/10. 1007/s13365-012-0103-4

Yeung MC, Pulliam L, Lau AS (1995) The HIV envelope protein gp120 is toxic to human brain-cell cultures through the induction of interleukin-6 and tumor necrosis factor-alpha. AIDS 9(2):137-143. https://doi.org/10.1097/00002030-199509020-00004

Zink MC, Suryanarayana K, Mankowski JL, Shen A, Piatak M Jr, Spelman JP, Carter DL, Adams RJ, Lifson JD, Clements JE (1999) High viral load in the cerebrospinal fluid and brain correlates with severity of simian immunodeficiency virus encephalitis. J Virol 73(12):10480-10488 